DOI: https://doi.org/10.24127/ajpm.v10i2.3530

\title{
ANALISIS KESALAHAN SISWA SEKOLAH DASAR DALAM MENYELESAIKAN MASALAH MATEMATIKA BERDASARKAN NEWMAN
}

\author{
Rissa Prima Kurniawati ${ }^{*}$, Fida Rahmantika Hadi ${ }^{2}$ \\ ${ }^{1 *, 2}$ Universitas PGRI Madiun, Madiun, Indonesia \\ *Corresponding author \\ E-mail: $\quad \frac{\text { rissa@unipma.ac.id }}{\left.\text { fida@unipma.ac.id }^{*}\right)}$
}

Received 05 February 2021; Received in revised form 14 June 2021; Accepted 06 July 2021

\begin{abstract}
Abstrak
Banyak siswa kelas 5 Sekolah Dasar yang sering melakukan kesalahan ketika menyelesaikan masalah matematika, terutama pada kesalahan konsep dalam mengerjakan soal matematika. Penelitian ini bertujuan untuk menganalisis kesalahan siswa kelas 5 SD dalam menyelesaikan soal matematika HOTS berdasarkan Newman. Jenis penelitian pada penelitian ini adalah penelitian kualitatif. Subyek penelitian ini sebanyak enam siswa kelas 5 SD. Adapun teknik pengumpulan data meliputi tes, lembar wawancara, dan dokumentasi. Teknik analisis data dalam penelitian ini adalah reduksi data, penyajian data, dan penarikan kesimpulan. Berdasarkan hasil penelitian, kesalahan yang dilakukan oleh siswa kelas 5 SDN 02 Mojorejo Kota Madiun adalah kesalahan membaca (reading error), kesalahan memahami (comprehension error), kesalahan transformasi (transformation error), kesalahan keterampilan proses (process skill error), dan kesalahan jawaban akhir (encoding error). Kesalahan yang paling sering dilakukan adalah kesalahan ketrampilan proses dan kesalahan jawaban akhir. Beberapa faktor yang menyebabkan siswa melakukan kesalahan adalah siswa belum terbiasa dengan soal matematika HOTS, siswa tidak menuliskan apa yang diketahui dan ditanyakan dari soal dengan tepat, kurangnya penguasaan pada materi volume bangun ruang, dan siswa kurang teliti dalam menjawab soal matematika.
\end{abstract}

Kata kunci: High order thinking skills; kesalahan siswa; soal matematika.

\begin{abstract}
Many students in elementary school make mistakes when solving math problems, especially misconceptions in solving math problem. This is caused by a lack of mathematical material understanding, students are lazy to open mathematics books or notes, and students are lazy to do assignments given by the teacher. This study aims to analyze the mistakes of fifth grade elementary school students in solving HOTS math's problems based on Newman. This type of research in this research is qualitative research. The data collection techniques include tests, interviews, and documentation. Data analysis techniques in this study were data reduction, data presentation, and conclusion drawing. Based on the results of the study, the mistakes made by fifth grade students of SDN 02 Mojorejo Kota Madiun were reading errors, comprehension errors, transformation errors, process skill errors, and answer errors. end (encoding error). The most frequent mistakes made were process skills errors and answer errors. Some of the factors that cause students to make mistakes are students who are not familiar with HOTS math problems, students do not write down what is known and asked from the questions, lack of mastery on the material of volume shapes, and students are not careful in answering math questions.
\end{abstract}

Keywords: High order thinking skills; math problem; student errors.

This is an open access article under the Creative Commons Attribution 4.0 International License

\section{PENDAHULUAN}

Matematika

adalah

suatu

pelajaran wajib di Sekolah Dasar. Pada pelajaran matematika memiliki fakta, konsep, dan operasi berkarakter abstrak (Oktaviana, 2018). Konsep dan operasi matematika ini sangat berguna bagi siswa untuk masa depannya. 
Matematika merupakan ratu dari semua ilmu (Hartati, 2015). Hal ini dikarenakan semua konsep dalam matematika dapat dikembangkan dan berguna pada ilmu maupun bidang yang lain. Ilmu maupun konsep matematika dapat bermanfaat di kehidupan seharihari, misalnya menghitung tabungan, membeli dan menjual barang, menghitung keuntungan dan kerugian, dan membaca jam. Kegunaan yang lainnya yaitu untuk membuat masker. Dalam membuat masker ini membutuhkan perhitungan matematika seperti penjumlahan bilangan, sehingga masker ini sesuai dan dapat dipakai oleh semua kalangan baik anak-anak maupun orang dewasa.

Matematika juga sering disebut sebagai jembatan yang menghubungkan antara teori dengan impelementasinya dalam berbagai kegiatan (Katz, 2015). Dengan menghubungkan suatu konsep materi matematika dengan kehidupan yang nyata dapat bermanfaat untuk siswa yaitu untuk pemahaman konsep matematika dengan cepat dan membantu sdalam penyelesaian masalah matematika dengan tepat.

Proses kegiatan pembelajaran matematika diupayakan untuk membentuk siswa-siswi yang hebat, aktif, kreatif, cerdas, dan memiliki semangat bekerja keras yang tinggi. Upaya yang dilakukan seperti selalu melakukan kreatifitas di segala bidang diantaranya dalam mengajar di kelas, dan penggunaan model serta media pembelajaran yang bervariasi setiap harinya. Sehingga tercipta pembelajaran matematika yang menyenangkan.

Tujuan pembelajaran matematika dalam kurikulum 2013 meliputi siswa dapat menyelesaikan permasalahan tentang matematika, memecahkan masalah sehari-hari dengan kemampuan bernalar dan analisisnya. Pemecahan masalah matematika yang lebih kompleks yaitu terdapat pada suatu soal cerita. Ketika menyelesaikan soal cerita, siswa diminta untuk membaca soal, memahami soal, memahami konsep materi matematika, dan menentukan langkah yang benar dalam menyelesaikan soal. Sehingga akan memudahkan dan membantu siswa dalam meningkatkan pemahaman tentang konsep dan soal, menentukan langkah penyelesaian matematika dengan menggunakan rumus yang benar, runtut, dan terstruktur dalam menyelesaikan masalah matematika (Farhan \& Zulkarnain, 2019).

Berdasarkan hasil pengamatan di SD Negeri 02 Mojorejo Kota Madiun pada siswa kelas 5, banyak siswa yang jarang senyum, kurang motivasi, dan kurang minat dalam belajar matematika sehingga nilai matematika siswa tidak sesuai dengan harapan. Terdapat beberapa hal yang membuat siswa kurang tertarik pada pelajaran matematika, yaitu banyaknya bilangan yang ada dibuku teks, konsep perhitungan yang tidak mudah dan rumit, terlalu banyak aturan dan rumus dalam matematika. Beberapa hal tersebut membuat siswa kurang berminat dan tertarik dengan matematika.

Ditambah lagi guru kurang kreatif dalam penggunaan model dan media pembelajaran. Hal inilah, yang membuat siswa menjadi tidak berminat belajar matematika. Satu materi yang dianggap sulit oleh siswa adalah materi volume bangun ruang. Banyak siswa merasa kesulitan ketika diminta mengerjakan soal volume bangun ruang dan ditambah lagi siswa kesulitan ketika ada tugas mengerjakan soal cerita volume bangun ruang. Sehingga, siswa cenderung mengerjakan soal tersebut dengan tidak semangat dan hnaya 
mencontoh pekerjaan temannya. Hal ini sering menimbulkan terjadinya kesalahan dalam menjawab soal.

Hasil ulangan harian pelajaran matematika di SDN 02 Mojorejo dapat diketahui bahwa nilai siswa yang dibawah KKM $65 \%$ dan $35 \%$ siswa mendapatkan nilai di atas KKM. Dan juga menurut hasil survei PISA untuk literasi matematika pada tahun 2018 di Indonesia masih tergolong rendah karena Indonesia berada pada peringkat 72 dengan skor 379. Hal ini menunjukkan prestasi belajar matematika masih termasuk rendah. Rendahnya prestasi belajar matematika ini disebabkan oleh literasi matematis yang rendah dan siswa sering membuat kesalahan dalam menyelesaikan soal matematika, misalnya pada soal cerita. Menyelesaikan soal cerita pada pelajaran matematika bukan hanya untuk memperoleh jawaban yang benar, tetapi yang penting siswa harus bisa menentukan langkah-langkah dalam mencari jawaban yang benar. Langkahlangkah dalam menjawab suatu soal cerita yaitu membaca dan memahami soal, membuat langkah-langkah penyelesaian, dan menyimpulkan (Toha et al., 2018).

Siswa kelas 5 sering melakukan kesalahan dalam menjawab soal cerita, hal ini dikarenakan soal cerita sulit untuk dipahami dan diselesaikan (Adhim \& Amin, 2019). Adapun jenis kesalahan dalam menyelesaikan masalah matematika yaitu kesalahan yang berkaitan dengan konsep, kesalahan dalam menggunakan data, kesalahan dalam interpretasi bahasa, kesalahan teknis, dan kesalahan dalam menarik kesimpulan (Toha et al., 2018).

Kesalahan siswa dalam menjawab soal matematika perlu diperiksa lebih lanjut untuk mendapatkan gambaran yang jelas dan tepat tentang permasalahan yang dialami siswa dalam memecahkan masalah matematika (Nurussafa'at et al., 2016). Kesalahan siswa disebabkan beberapa faktor, yaitu kesalahan dalam menerima informasi, siswa kurang teliti dalam menjawab, dan salah memasukkan angka kedalam rumus.

Banyak siswa di Sekolah Dasar kurang mampu dalam menjawab soal cerita terutama pada soal HOTS. Hal ini dikarenakan guru yang kurang dalam memberikan soal matematika HOTS dan banyak siswa kurang semangat dalam mengerjakan soal maupun tugas matematika yang diberikan oleh guru. Soal HOTS (High Order Thinking Skills) merupakan ciri pada kurikulum 2013 karena soal cerita dengan tipe HOTS dapat membantu siswa dalam berpikir kritis, metakognitif, dan berpikir kreatif (Suryapuspitarini et al., 2018).

Prosedur yang dapat digunakan untuk menganalisis kesalahan siswa adalah NEA (Newman Error Analysis). Newman merupakan suatu metode yang digunakan untuk menganalisis suatu kesalahan soal dalam bentuk uraian (Darmawan et al., 2018). Langkahlangkah NEA ada 5 tahapan yaitu, Reading (membaca), Comprehension (memahami masalah), Transformation (transformasi), Process skills (keterampilan proses) dan Encoding (menuliskan jawaban akhir) (Lestari et al., 2018). Dalam penelitian yang dilakukan oleh Safitri et al. (2019) tentang analisis kesalahan siswa dalam menyelesaikan soal cerita bangun datar berdasarkan NEA didapatkan hasil bahwa kesalahan dalam membaca $13,3 \%$, kesalahan dalam memahami soal $10,89 \%$, kesalahan transformasi sebanyak 27,62\%, kesalahan keterampilan proses sebanyak $15,73 \%$, dan kesalahan menulis jawaban 
sebanyak 32,45\%. Sedangkan dalam penelitian ini, soal cerita yang digunakan berupa soal HOTS pada materi volume bangun ruang.

Analisis kesalahan matematis ini sangat diperlukan, agar guru dapat memperbaiki kesalahan-kesalahan yang dilakukan siswa dalam menyelesaikan soal matematika. Dan juga guru mengetahui materi mana saja yang harus diajarkan lebih lama, sehingga siswa memahami konsep dan dapat dengan mudah menyelesaikan soal matematika. Penelitian ini bertujuan untuk menganalisis kesalahan siswa kelas 5 SD dalam menyelesaikan soal matematika HOTS berdasarkan Newman.

\section{METODE PENELITIAN}

Jenis penelitian yang digunakan adalah kualitatif. Tahapan penelitian kualitatif meliputi menentukan permasalahan dalam pembelajaran matematika, menentukan fokus penelitian, pengumpulan data, dan analisis data.

Subjek penelitian ini adalah siswa kelas 5 SDN 02 Mojorejo Kota Madiun sebanyak enam siswa yang terdiri dari dua siswa memiliki kemampuan yang tinggi, dua siswa memiliki kemampuan sedang, dan dua siswa memiliki kemampuan rendah. Teknik pengumpulan data pada penelitian ini adalah tes, wawancara, dan dokumentasi. Pertama, tes digunakan untuk mengetahui kemampuan kognitif siswa kelas 5 SDN 02 Mojorejo. Tes pada penelitian ini berupa soal uraian sebanyak 5 soal dengan materi volume bangun ruang. Kedua adalah wawancara, wawancara yang digunakan adalah wawancara tidak terstruktur. wawancara dilakukan untuk mendapatkan informasi yang lebih jelas, untuk mengetahui kesalahan yang dilakukan siswa dalam menyelesaikan soal matematika HOTS. Ketiga adalah dokumentasi. Dokumentasinya berupa silabus, buku pelajaran matematika kelas 5, dan lain-lain. Dokumentasi ini dibutuhkan untuk menambah pemahaman dan informasi yang diperlukan untuk penelitian. Teknik analisis data yang digunakan adalah reduksi data, penyajian data, dan penarikan kesimpulan (Sugiyono, 2013). Pertama, reduksi data. Reduksi data dalam penelitian ini dilakukan terus sesudah penelitian di lapangan, sampai laporan akhir tersusun dengan lengkap. Reduksi data dianalisis berupa hasil tes tulis dan wawancara. Kedua yaitu penyajian data. Penyajian data berbentuk uraian yang jelas, tabel, dan bagan, sehingga memudahkan peneliti untuk memahami tentang data penelitian. Ketiga adalah penarikan kesimpulan. Kesimpulan berupa temuan penelitian yang baru atau belum pernah ada pada temuan penelitian sebelumnya. Prosedur penelitian dalam penelitian ini adalah persiapan, penentuan masalah, membuat instrumen penelitian, pelaksanaan penelitian, analisis data, dan membuat laporan penelitian.

\section{HASIL DAN PEMBAHASAN}

Subjek pada penelitian ini sebanyak enam siswa meliputi siswa berkemampuan tinggi yaitu S01 dan S02, siswa berkemampuan sedang yaitu S03 dan S04, dan siswa berkemampuan rendah yaitu S05 dan S06. Mereka akan mengerjakan lima soal cerita bertipe HOTS pada materi volume bangun ruang (kubus dan balok) yang diberikan oleh guru. Adapun indikator kesalahan dalam mengerjakan soal dapat diketahui pada Tabel 1. 
DOI: https://doi.org/10.24127/ajpm.v10i2.3530

Tabel 1. Indikator kesalahan berdasarkan Newman

\begin{tabular}{|c|c|c|}
\hline & $\begin{array}{c}\text { Tahapan dalam Analisis } \\
\text { Kesalahan Newman }\end{array}$ & Indikator Kesalahan \\
\hline 1. & Membaca (Reading) & $\begin{array}{l}\text { a. Siswa tidak dapat membaca atau mengenali simbol } \\
\text { pada soal matematika } \\
\text { b. Siswa tidak mampu memahami arti atau simbol } \\
\text { setiap kata, istilah atau simbol dalam soal }\end{array}$ \\
\hline 2. & $\begin{array}{l}\text { Memahami } \\
\text { (Comprehension) }\end{array}$ & $\begin{array}{l}\text { a. Tidak menulis apa yang diketahui dan ditanyakan } \\
\text { b. Salah menulis apa yang diketahui pada soal } \\
\text { c. Menuliskan apa yang diketahui } \\
\text { d. Kesalahan memahami perintah yang ditanyakan } \\
\text { pada soal }\end{array}$ \\
\hline 3. & $\begin{array}{l}\text { Transformasi } \\
\text { (Transformation) }\end{array}$ & $\begin{array}{l}\text { a. Salah dalam menentukan rumus } \\
\text { b. Tidak mengubah informasi ke dalam bentuk model } \\
\text { matematika } \\
\text { c. Mengubah informasi ke dalam bentuk matematika } \\
\text { tapi tidak tepat. }\end{array}$ \\
\hline 4. & $\begin{array}{l}\text { Keterampilan Proses } \\
\text { (Process Skill) }\end{array}$ & $\begin{array}{l}\text { a. Tidak dapat melanjutkan proses penyelesaian } \\
\text { b. Dapat melanjutkan proses penyelesaian tetapi tidak } \\
\text { tepat, karena salah konsep } \\
\text { c. Keliru dalam proses penghitungan }\end{array}$ \\
\hline 5. & $\begin{array}{l}\text { Jawaban Akhir } \\
\text { (Encoding) }\end{array}$ & $\begin{array}{l}\text { a. Tidak menuliskan variabel/satuan } \\
\text { b. Salah dalam menggunakan satuan } \\
\text { c. Tidak menuliskan variabel/satuan } \\
\text { d. Salah dalam menggunakan satuan }\end{array}$ \\
\hline
\end{tabular}

(Mulyani \& Muhtadi, 2019)

Berikut hasil analisis kesalahan siswa:

\section{1) Kesalahan Siswa 01 (S01)}

Skor yang didapat S01 adalah 90. Berdasarkan jawaban S01, dapat diketahui bahwa S01 dapat menjawab dengan tepat dan benar pada soal nomor 1 , soal nomor 2, soal nomor 3, dan soal nomor 5. Akan tetapi S01 kurang tepat dalam menjawab soal nomor 4. Gambar 1. berikut adalah hasil jawaban S01 pada soal nomor 4 .

4. D: bak mandi dengan air $\frac{3}{5}$ bagian

Tebal bak : $10 \mathrm{dm}$

Sisi bak : $25 \mathrm{dm}$

T: $\quad \mathrm{V}$ bak mandi

$\mathrm{J}: \quad \mathrm{V}$ kubus $=s^{3}=25^{3}$

$$
=15625
$$

Gambar 1. Hasil Jawaban S01 Nomor 4
Pada soal nomor 4, S01 hanya melakukan beberapa kesalahan yaitu keterampilan proses dan kesalahan jawaban akhir. Kesalahan keterampilan proses pada S01 yaitu, siswa tidak melanjutkan proses menghitung atau ke langkah selanjutnya. S01 hanya menghitung volume bak mandi saja sehingga S01 belum membagi volume bak mandi dengan volume air yaitu $\frac{3}{5} \times 25^{2}-10^{2}$. Sehingga jawaban akhir yang ditulis S01 salah. Berdasarkan wawancara yang dilakukan dengan S01 diketahui bahwa S01 mampu membaca semua soal dengan baik namun S01 kurang tepat dalam menuliskan penyelesaian karena siswa kurang teliti dalam mengerjakan soal. 
DOI: https://doi.org/10.24127/ajpm.v10i2.3530

\section{2) Kesalahan Siswa 02 (S02)}

Skor yang didapatkan S02 adalah 98. Gambar 2. berikut ini adalah hasil jawaban S02 pada soal nomor 5.

5. Diketahui:

Panjang akuarium $11 \mathrm{dm}$

Lebar akuarium $11 \mathrm{dm}$

Tinggi akuarium $10 \mathrm{dm}$

Air di akuarium 9 meter

Ditanya: takaran berapa air tumpah ?

Jawab : V akuarium

$$
\begin{aligned}
& =p \times l \times t \\
& =11 \times 11 \times 10 \\
& =1210 \mathrm{dm}^{3} \\
& =1210 \div 9 \\
& =134,4
\end{aligned}
$$

Gambar 2. Hasil Jawaban S02 Nomor 5

Berdasarkan Gambar 2 diketahui informasi bahwa pada soal nomor 5, S02 hanya melakukan kesalahan jawaban akhir, karena siswa tidak menuliskan satuan. Dapat dilihat pada gambar 3 di atas, siswa tidak menuliskan satuan volume. Seharusnya siswa menuliskan jawaban akhir yaitu 134,4 liter. Berdasarkan hasil wawancara diketahui bahwa S02 mampu membaca semua soal dengan baik. S02 juga melakukan kesalahan yaitu pada jawaban nomor 5 yaitu kesalahan jawaban akhir. S02 tidak menuliskan satuan liter pada jawabannya. Hal ini disebabkan S02 kurang teliti dan terburu-buru dalam menyelesaikan soal tersebut.

\section{3) Kesalahan Siswa 03 (S03)}

Skor yang didapat S03 adalah 74 . Pada gambar 3 berikut merupakan hasil jawaban dari siswa 03 (S03).

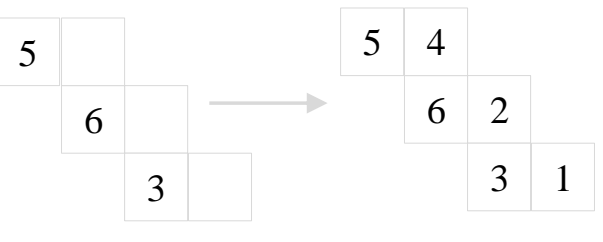

Gambar 3. Hasil Jawaban S03 Nomor 3

Pada gambar 3 diketahui bahwa pada soal nomor 3, S03 melakukan kesalahan transformasi, yaitu S03 langsung menjawab pertanyaan tanpa mengubah informasi dari soal ke bentuk matematika yang jelas, seharusnya siswa dapat menjawab dengan menuliskan beberapa langkah seperti gambar 4 .
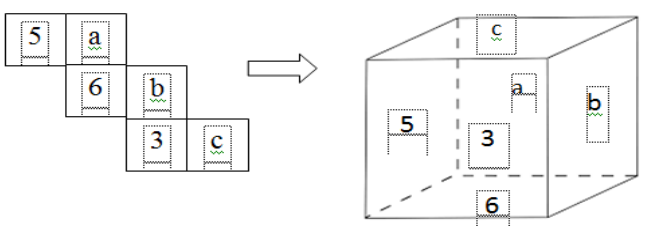

Gambar 4. Jaring-jaring Kubus

S03 juga melakukan kesalahan keterampilan proses karena siswa tidak menuliskan langkah penyelesaian yang benar dari soal yang diberikan oleh guru. Berdasarkan hasil wawancara diketahui bahwa S03 mampu membaca hampir semua soal dengan baik, namun S03 masih melakukan kesalahan ketrampilan proses dan kesalahan transformasi. Hal ini dikarenakan S03 malas menuliskan langkah-langkah penyelesaian soal.

\section{4) Kesalahan Siswa 04 (S04)}

Pada gambar 5 di bawah ini adalah hasil jawaban dari siswa 04 (S04). Dan skor yang didapatkan S04 yaitu 74 . 
1. Diketahui :

luas alas koper $400 \mathrm{~cm}^{2}$

Luas alas kotak pensil $200 \mathrm{~cm}^{2}$

Tinggi koper yang berisi bola $25 \mathrm{~cm}$

Tinggi koper yang berisi bola dan

tempat pensil $30 \mathrm{~cm}$

Ditanya :tinggi kotak pensil

Jawab :

Volume koper yangdiisi kotak pensil

$=$ Luas alas tas koper

$$
\begin{aligned}
& \times(\text { t.awal } \\
& - \text { t.akhir }) \\
= & 400 \mathrm{~cm}^{2} \times(30 \mathrm{~cm}-25 \mathrm{~cm}) \\
= & 400 \times 5 \mathrm{~cm} \\
= & 20000 \mathrm{~cm}^{3}
\end{aligned}
$$

Gambar 5. Hasil Jawaban S04 Nomor 1

Berdasarkan Gambar 5 diperoleh informasi bahwa soal nomor 1, S04 melakukan kesalahan keterampilan proses dan kesalahan jawaban akhir, yaitu S04 tidak dapat menyelesaikan soal sampai menemukan jawaban akhir yang benar. Dapat dilihat ada gambar 5 di atas, setelah menentukan volume koper yang diisi dengan kotak pensil, S04 tidak menyelesaikan langkah selanjutnya yaitu menentukan tinggi kotak pensil. Akibatnya, jawaban akhirnya salah. Sehingga S04 melakukan kesalahan dalam menentukan jawaban akhir. Pada soal nomor 5, S04 melakukan kesalahan jawaban akhir, karena siswa juga tidak menuliskan satuan volume. Seharusnya siswa menuliskan jawaban akhir yaitu 135 liter.

Berdasarkan hasil wawancara, S04 melakukan suatu kesalahan keterampilan proses dan menentukan jawaban akhirnya. Hal ini dikarenakan S04 kurang memahami konsep materi yang diberikan oleh guru dan S04 belum bisa menentukan langkah yang tepat dalam menyelesaikan soal tersebut.

\section{5) Kesalahan Siswa 05 (S05)}

Pada gambar 6 adalah hasil jawaban dari siswa 05 (S05). Skor yang didapatkan S05 yaitu 49.

2. Diketahui :

Rusuk kubus kecil $24 \mathrm{~cm}$

Rusuk kubus besar $=7 \times 4=28 \mathrm{~cm}$

Ditanya : V kubus besar?

Dijawab :

$V=r^{3}$

$V=r^{3}=28 \mathrm{~cm}$

$=21952 \mathrm{~cm}^{3}$

5: $4 \quad 6: 2 \quad 3: 1$

Gambar 6. Hasil Jawaban S05 Nomor 2

Berdasarkan Gambar 6 didapatkan informasi bahwa pada soal nomor 3, S05 melakukan kesalahan memahami yaitu S05 tidak menuliskan apa yang diketahui dari soal dan yang ditanyakan pada soal. S05 juga melakukan kesalahan transformasi yaitu S05 tidak paham tentang permasalahan yang diberikan, S05 kurang memahami dalam menentukan rumus yang digunakan dalam menyelesaikan soal tersebut.

S05 juga kesalahan keterampilan proses yaitu siswa menjawab soal dengan asal-asalan seperti siswa menuliskan perbandingan 5:4 6:2 3:1 sehingga siswa tidak mengetahui langkah menghitung dengan tepat, sehingga jawaban akhir S05 menjadi tidak tepat. Pada Gambar 7 adalah hasil jawaban S05 pada nomor 4 dan nomor 5. Berdasarkan Gambar 7, diperoleh informasi bahwa pada soal nomor 4, S05 melakukan kesalahan membaca, yaitu tidak jelas dalam menulis yang diketahui dari soal seperti bak mandi $25-2025-10$. S05 juga melakukan kesalahan transformasi, yaitu salah dalam menentukan rumus, misalnya S05 menuliskan rumus balok $p \times l \times t$ seharusnya berbentuk kubus dengan 
DOI: https://doi.org/10.24127/ajpm.v10i2.3530

rumus $\quad s \times s \times s . \quad$ Kesalahan keterampilan proses yang dilakukan S05 adalah S05 salah menuliskan rumus untuk menyelesaikan soal matematika. Kesalahan tersebut menyebabkan S05 salah dalam menemukan jawaban akhir.

4. Diketahui :

Bak mandi 25-20, 25-10

Ditanya : V air?

Dijawab :

$V=p \times l \times t$

$V=(25-20) \times(25-30) \times(25$ $-10)$

$=5 \times 5 \times 15$

$=375 \mathrm{dm}^{3}$

$V$ air $=\frac{3}{5} \times 375$

$=225 \mathrm{dm}^{3}$

5. Diketahui : $\mathrm{p}=11 \mathrm{dm}=11 \mathrm{dm}$ lebar $=11 \mathrm{dm}=11 \mathrm{dm}$

Dijawab :

tinggi $=1 \mathrm{~m}=10 \mathrm{dm}$

$V=p \times l \times t$

$V=11 \times 11 \times 10$

$V=1210 \mathrm{dm}^{3}=1210$ liter

ditanya : berapa ember..?

jawab : $\frac{1210}{9}=135$ ember

Jadi akuarium akan terisi penuh setelah diisi 135 ember

\section{Gambar 7. Hasil Jawaban Siswa S05}

Soal nomor 5, S05 melakukan kesalahan memahami dan kesalahan jawaban akhir yaitu S05 menuliskan pada lembar jawabannya 135 ember, sedangkan jawaban yang tepat adalah 135 liter. S05 kurang memahami soal yang diberikan oleh guru. Berdasarkan hasil wawancara, S05 belum memahami konsep matematika dan kurang paham dalam menentukan langkah penyelesaian yang tepat untuk menjawab soal itu. Sehingga S05 banyak melakukan kesalahan yaitu kesalahan memahami, kesalahan transformasi, keterampilan proses, dan kesalahan jawaban akhir.

\section{6) Kesalahan Siswa 06 (S06)}

Pada gambar 8 adalah hasil jawaban dari siswa 06 (S06). Skor yang didapatkan S06 yaitu 21.

1. $38 \mathrm{~cm}^{2}$ ting ginya

2. $4^{3} \times 343=64 \times 343=21952 \mathrm{~cm}^{3}$ $=28 \mathrm{~cm}$

3. 54

$$
\begin{array}{|l|l|l|}
6 & 2 & \\
\hline & 3 & 1 \\
\hline
\end{array}
$$

4. Panjang : $90-10-10=70 \mathrm{~cm}=70 \mathrm{~m}$ Lebar : $90-10-10=70 \mathrm{~cm}=70 \mathrm{~m}$

Tinggi : $70-10=60 \mathrm{~cm}=60 \mathrm{~m}$

Bak terisi $\frac{1}{4}$

Maka volume air?

$V=\frac{1}{4} \times 7 \times 7 \times 6$

$V=73,5 \mathrm{~cm}^{3}$

5. $=p \times l \times t$

$=11 \mathrm{~cm} \times 77 \mathrm{~cm} \times 100 \mathrm{~cm}$

$=1210 \mathrm{dm}^{3}$

$=1210$ liter

Volume akuarium, Volume ember

$=1210$ liter $: 9$ liter

$=134,4$

\section{Gambar 8. Hasil Jawaban S06}

Berdasarkan Gambar 8, diketahui bahwa pada soal nomor 1, S06 melakukan kesalahan memahami, yaitu tidak menuliskan yang diketahui dan yang ditanyakan. S06 hanya asal menuliskan jawaban yaitu $38 \mathrm{~cm}^{2}$. Hal ini juga menimbulkan kesalahan transformasi, keterampilan proses, dan jawaban akhir.

Pada soal nomor 2, S06 melakukan kesalahan memahami, yaitu tidak menuliskan yang diketahui dan yang ditanyakan dari soal. S06 juga melakukan kesalahan transformasi, yaitu salah dalam menggunakan rumus dalam menjawab soal. Karena S06 tidak memahami rumus yang harus digunakan dalam menjawab soal tersebut. S06 juga melakukan kesalahan ketrampilan 
proses, yaitu S06 menuliskan perkalian $4^{3} \times 343$. Penyelesaian tersebut salah karena berbeda dengan jawaban yang benar. Jawaban akhir S06 juga salah. Sehingga S06 melakukan kesalahan jawaban akhir.

Berdasarkan soal nomor 3, S06 melakukan kesalahan memahami dan transformasi, yaitu tidak menuliskan yang diketahui dan yang ditanyakan dari soal. Kesalahan transformasi yang dilakukan S06 yaitu S06 langsung menjawab pertanyaan tanpa mengubah informasi dari soal ke dalam bentuk matematika yang benar. S06 juga melakukan kesalahan keterampilan proses karena S06 tidak menuliskan langkah-langkah penyelesaian yang tepat dalam menjawab soal tersebut.

Pada soal nomor 4, S06 melakukan kesalahan memahami yaitu tidak menuliskan yang diketahui dan yang ditanyakan pada soal. S06 menjawab soal dengan sesuka hatinya, karena tidak memahami rumus yang digunakan dalam menjawab soal tersebut dan tidak memahami isi soal. Hal ini juga menyebabkan kesalahan keterampilan proses, karena salah dalam melakukan penghitungan. Akibat dari kesalahan-kesalahan di atas menyebabkan S06 melakukan kesalahan dalam menentukan jawaban akhir.

Soal nomor 5, S06 melakukan kesalahan memahami dan kesalahan jawaban akhir, contohnya S06 juga tidak menuliskan satuan volume. Berdasarkan hasil wawancara, S06 banyak melakukan kesalahan yaitu kesalahan memahami, kesalahan transformasi, keterampilan proses, dan kesalahan jawaban akhir. Hal ini dikarenakan S06 malas membaca materi, malas mengerjakan tugas yang diberikan oleh guru, dan tidak memahami konsep materi matematika.

\section{Kesalahan yang Dilakukan Siswa Berdasarkan Prosedur Newman}
1. Kesalahan Membaca (Reading Error)

Kesalahan membaca ini dilakukan oleh S05. Kesalahan membaca yang dilakukan S05 meliputi salah membaca simbol baik pada penjumlahan maupun pengurangan, siswa salah membaca satuan volume, dan tidak mampu memaknai arti atau dalam soal. Hal ini sesuai pendapatnya Jamal (2018) yang mengungkapkan bahwa kesalahan membaca yaitu siswa tidak dapat membaca suatu kata atau simbol yang terdapat dalam soal. Faktor penyebab siswa melakukan kesalahan membaca yaitu tidak terbiasa membaca soal-soal matematika, belum bisa membedakan satuan luas dan volume, keliru saat membaca simbol penjumlahan dan pengurangan, dan kurang meminati pelajaran matematika.

\section{Kesalahan Memahami} (Comprehension Error)

Kesalahan memahami ini dilakukan oleh S05 dan S06. Kesalahan memahami yang dilakukan S05 dan S06 yaitu tidak menuliskan hal yang diketahui dan yang ditanyakan, ada juga beberapa yang menuliskan tapi tidak lengkap. Hal ini sesuai dengan pendapatnya Rahayuningsih \& Qohar (2014) yang menjelaskan bahwa kesalahan memahami terjadi ketika siswa tidak menuliskan keterangan yang ada pada soal dan apa yang harus dilakukan oleh siswa untuk menjawab soal misalnya siswa tidak menuliskan yang diketahui dari soal dan siswa tidak menuliskan yang ditanyakan dari soal dengan lengkap. Faktor yang menyebabkan siswa melakukan kesalahan memahami adalah tidak mengetahui hal yang diketahui dan yang ditanyakan pada soal, tidak terbiasa 
menulis hal yang diketahui dan ditanyakan pada soal, menuliskan hal yang diketahui, tetapi tidak lengkap, kurang teliti menemukan hal yang diketahui pada soal, tidak mengetahui permasalahan pada soal, bingung untuk menulis apa yang diketahui dan ditanyakan yang terdapat pada soal, dan terburu-buru untuk menyelesaikan soal.

\section{Kesalahan Transformasi}

(Transformation Error)

Siswa yang melakukan kesalahan transformasi adalah S03, S05, dan S06. Kesalahan transformasi yang dilakukan siswa tersebut meliputi salah menentukan rumus yang digunakan untuk menyelesaikan masalah, siswa tidak mengubah informasi kedalam bentuk matematika yang tepat, dan siswa melakukan kesalahan dalam mengubah informasi kedalam bentuk matematika. Hal ini sesuai dengan pendapatnya Harniati et al. (2019) yang menjelaskan bahwa kesalahan transformasi disebabkan karena siswa tidak mampu mengubah kalimat matematika ke dalam bentuk atau model matematika dan siswa tidak dapat menentukan rumus yang digunakan untuk menyelesaikan soal. Faktor yang menyebabkan siswa melakukan kesalahan transformasi yaitu tidak mengetahui rumus yang harus digunakan, tidak mengetahui langkahlangkah yang tepat dalam menyelesaikan soal, tidak paham dengan materi bangun ruang kubus dan balok, dan tidak memiliki penguasaan materi yang cukup.

\section{Kesalahan Keterampilan Proses (Process Skill Error)}

Siswa yang melakukan kesalahan keterampilan proses adalah S01, S03, S04, S05, dan S06. Kesalahan keterampilan proses yang dilakukan siswa tersebut yaitu tidak dapat melanjutkan proses penyelesaian pada tahap selanjutnya, siswa mampu melakukan proses penyelesaian tapi tidak tepat, siswa salah melakukan proses penghitungan. Hal tersebut sesuai dengan pendapat Rahayuningsih \& Qohar (2014) yang menyatakan bahwa kesalahan keterampilan proses yang dilakukan siswa yaitu siswa tidak menuliskan langkah-langkah dalam menyelesaikan soal dengan tepat, siswa tidak melakukan langkah selanjutnya dalam menemukan jawaban akhir, dan kesalahan dalam proses bilangan. Beberapa faktor penyebab siswa melakukan kesalahan keterampilan proses meliputi siswa kurang teliti dalam melakukan proses penghitugan, tidak dapat menyelesaikan jawaban secara tuntas, asal-asalan dalam menuliskan jawaban, dan siswa terburuburu dalam mengerjakan soal.

\section{Kesalahan Jawaban Akhir (Encoding Error)}

Adapun siswa yang melakukan kesalahan jawaban akhir adalah S01, S02, S04, S05, dan S06. Kesalahan jawaban akhir yang dilakukan siswa tersebut yaitu, siswa yang tidak menuliskan variabel/satuan, siswa salah menggunakan satuan, dan siswa kurang teliti dalam mengerjakan soal. Hal ini sejalan dengan pendapat Amalia et al. (2018) bahwa kesalahan jawaban akhir pada siswa dikarenakan siswa tidak menuliskan hasil akhir sesuai dengan langkah-langkah yang sesuai dan siswa kurang teliti dalam menyelesaikan masalah matematika. Beberapa faktor penyebab siswa melakukan kesalahan jawaban akhir adalah siswa lupa menuliskan satuan pada akhir jawaban dan siswa tergesa-gesa dalam menuliskan kesimpulan dari soal. 
DOI: https://doi.org/10.24127/ajpm.v10i2.3530

Berdasarkan hasil pembahasan dapat diketahui kesalahan yang sering dilakukan oleh siswa adalah kesalahan keterampilan proses dan kesalahan jawaban akhir. siswa yang melakukan kesalahan keterampilan proses sebanyak lima orang meliputi S01, S03, S04, S05, dan S06. Sedangkan siswa yang melakukan kesalahan jawaban akhir ada lima orang yaitu S01, S02, S04, S05, dan S06. Hal ini dikarenakan, siswa kurang teliti dan tergesa-gesa dalam menjawab soal tersebut, serta siswa tersebut belum memahami langkahlangkah yang tepat dalam menyelesaikan soal tersebut. Dengan mengetahui kesalahan yang sering dilakukan siswa ini, guru dapat memberikan treatment kepada siswa seperti lebih sering memberikan soal matematika HOTS dan guru memberikan scaffolding kepada siswa yang kurang memahami konsep atau siswa yang mendapatkan nilai yang di bawah KKM. Sehingga siswa dapat memperbaiki kesalahan yang dilakukannya dan siswa dapat menyelesaikan masalah matematika dengan tepat.

\section{KESIMPULAN DAN SARAN}

Berdasarkan hasil penelitian dapat diketahui bahwa kesalahan yang dilakukan siswa kelas 5 SDN 02 Mojorejo Kota Madiun dalam menyelesaikan soal matematika HOTS. Siswa yang melakukan kesalahan membaca sebanyak satu orang yaitu S05 dengan prosentase $16,67 \%$. Siswa yang melakukan kesalahan memahami meliputi S05 dan S06, dengan persentase $33 \%$. Siswa yang melakukan kesalahan transformasi sebanyak tiga siswa yaitu S03, S05, dan S06, dengan prosentase $50 \%$. Siswa yang melakukan kesalahan keterampilan proses sebanyak lima orang meliputi S01, S03, S04, S05, dan S06, dengan prosentase 83,33\%. Sedangkan siswa yang melakukan kesalahan jawaban akhir ada lima orang yaitu S01, S02, S04, S05, dan S06, dengan persentase $83,33 \%$.

Faktor-faktor yang menyebabkan siswa melakukan kesalahan yaitu siswa belum terbiasa dengan soal matematika HOTS, siswa tidak menuliskan apa yang diketahui dan yang ditanyakan dari soal, kurangnya penguasaan materi volume bangun ruang, dan siswa kurang teliti dalam menjawab soal matematika. Berdasarkan hasil penelitian dan pembahasan ini, guru di sekolah dasar diminta untuk lebih sering memberikan soal HOTS berupa soal cerita, agar siswa lebih terbiasa dengan soal HOTS dan untuk meningkatkan kemampuan literasi matematis siswa kelas 5 SD dalam menyelesaikan masalah matematika. Untuk peneliti selanjutnya dapat meneliti kesalahan siswa dalam menjawab soal-soal AKM numerasi dan literasi.

\section{DAFTAR PUSTAKA}

Adhim, B. F., \& Amin, S. M. (2019). MATHE dunesa. Mathe Dunesa Jurnal Ilmiah Pendidikan Matematika, 8(2), 169-173.

Amalia, R., Aufin, M., \& Khusniah, R. (2018). Analisis Kesalahan Dalam Menyelesaikan Soal Cerita pada Pokok Bahasan Persamaan Linier Berdasarkan Newman Kelas X-Mia di SMA Bayt Al-Hikmah Kota Pasuruan. Seminar Nasional Matematika Dan Pendidikan Matematika, II, 346-359.

Darmawan, I., Kharismawati, A., Hendriana, H., \& Purwasih, R. (2018). Analisis Kesalahan Siswa SMP Berdasarkan Newman dalam Menyelesaikan Soal Kemampuan Berpikir Kritis Matematis pada Materi Bangun Ruang Sisi Datar. JURING (Journal for Research in Mathematics Learning), 1(1), 71. 
DOI: https://doi.org/10.24127/ajpm.v10i2.3530

https://doi.org/10.24014/juring.v1i1.4 912

Farhan, M., \& Zulkarnain, I. (2019). Analisis Kesalahan Mahasiswa pada Mata Kuliah Kalkulus Peubah Banyak Berdasarkan Newmann' $s$ Error Analysis. 2682(2), 121-134.

Harniati, E., Jeharut, M., Hariyani, S., \& Wulandari, T. C. (2019). Analisis kesalahan menyelesaikan soal cerita berdasarkan tahapan newman ditinjau dari gender. 2, 575-582.

Hartati, L. (2015). Pengaruh Gaya Belajar dan Sikap Siswa pada Pelajaran Matematika terhadap Hasil Belajar Matematika. Formatif: Jurnal Ilmiah Pendidikan MIPA, 3(3), 224-235. https://doi.org/10.30998/formatif.v3i 3.128

Jamal, F. (2018). Analisis Kesalahan Dalam Menyelesaikan Soal Cerita Pertidaksamaan Kuadrat Berdasarkan Prosedur Newman. Maju (Jurnal Ilmiah Pendidikan Matematika), 5(2), 41-51.

Katz, A. (2015). Journal of Technology and Science Education. Journal of Technology and Science Education, 5(3), 184-193.

Lestari, A. S., Aripin, U., \& Hendriana, H. (2018). Identifikasi Kesalahan Siswa Smp Dalam Menyelesaikan Soal Kemampuan Penalaran Matematik Pada Materi Bangun Ruang Sisi Datar Dengan Analisis Kesalahan Newman. JPMI (Jurnal Pembelajaran Matematika Inovatif), 1(4), 493. https://doi.org/10.22460/ jpmi.v1i4.p493-504

Mulyani, M., \& Muhtadi, D. (2019). Analisis Kesalahan Siswa Dalam Menyelesaikan Soal Trigonometri Tipe Higher Order Thinking Skill Ditinjau Dari Gender. Jurnal Penelitian Dan Pembelajaran Matematika, 12(1), 1-16. https://doi.org/10.30870/jppm.v12i1. 4851

Nurussafa'at, F. A., Sujadi, I., \& Riyadi. (2016). Analisis kesalahan siswa dalam menyelesaikan soal cerita pada materi volume prisma dengan fong's shcematic model for error analysis ditinjau dari gaya kognitif siswa. Jurnal Elektronik Pembelajaran Matematika, 4(2), 174-187.

Oktaviana, D. (2018). Analisis Tipe Kesalahan Berdasarkan Teori Newman Dalam Menyelesaikan Soal Cerita Pada Mata Kuliah Matematika Diskrit. Edu Sains: Jurnal Pendidikan Sains \& Matematika, 5(2), 22. https://doi.org/10.23971/eds.v5i2.719

Rahayuningsih, P., \& Qohar, A. (2014). Analisis Kesalahan Menyelesaikan Soal Cerita Sistem Persamaan Linear Dua Variabel (Spldv) Dan Scaffolding-Nya Berdasarkan Analisis Kesalahan Newman Pada Siswa Kelas Viii Smp Negeri 2 Malang. Jurnal Pendidikan Matematika Dan Sains, 2(2), 109116.

https://doi.org/10.21831/jpms.v4i2.7 161

Safitri, F. A., Sugiarti, T., \& Hutama, F. S. (2019). Analisis Kesalahan Siswa dalam Menyelesaikan Soal Cerita Bangun Datar Berdasarkan Newman's Error Analysis (NEA). Jurnal Profesi Keguruan, 5(1), 4249.

Sugiyono. (2013). Metode Penelitian Kuantitatif, Kualitatif, dan $R \& D$ (19th ed.). Penerbit Alfabeta.

Suryapuspitarini, B. K., Wardono, \& Kartono. (2018). Analisis Soal-Soal Matematika Tipe Higher Order Thinking Skill ( HOTS ) pada Kurikulum 2013 untuk Mendukung Kemampuan Literasi Siswa. Prisma, Prosiding Seminar Nasional Matematika, 1, 876-884.

Toha, M., Mirza, A., \& Ahmad, D. (2018). Analisis kesalahan siswa dalam menyelesaikan soal cerita materi perbandingan di kelas VII SMP. Jurnal Pendidikan Dan Pembelajaran Khatulistiwa, 7(1), 110. http://jurnal.untan.ac.id/ index.php/jpdpb/article/view/23626/1 8546 